Imagine two cones joined together at their small ends like an hourglais, and that a solid of such a shape and size is turned out of walnut or cherry or boxwood or of ebony or ivory : this is the devil. Now take the last half-yard from the taper ends of two billiard-sticks, and let them be connected from these ends by a limp silken cord or string half a yard long these are the sticks.

To play the game hold the thick ends of the sticks one in each hand, bring the cord under the narrow neck of the solid and try to elevate it in the air : it drops directly on the grass. If a brisk rotary motion is given to it however, it will not only remain on the cord, but several dexterous manceuvres may be accomplished with it : the variety of which and the skill displayed in pertorming them constitute the game. To produce the revolutions the sticks are moved rapidly up and down alternately, and when the spinning is once established, "Diabolus" may be allowed to run up and down the stick, or he may be projected high up in the air, and, still spinning all the while, be caught on the $c$ ird again and again in rapid succession. Two may be engaged in the same game. It was fashionable many years since in these arts, and $I$ recillect seeing a picture in a Tunbridgeware ho $p$ in this place of the lords and ladies engaged in playing this game on the Pantiles at Tunbridge Wells more than half a century ago.

Bordyke Lodge, Tunbridge, June 4

[This is a nearly complete answer to our correspondent's query. The behaviour of the "devil" is an excellent example of that property of the axis of greatest or least moment of inertia of a body which is utilised in a well thrown quoit or an elongated rifle-bullet. The mode of producing the rotation is easy to learn by trial, but not very easy $t s$ describe. The sticks are kept moving so that one end of the cord is always at a greater tension than the other.-ED.]

\section{Channel Ballooning}

As I have shown in my pamphl t,, "Les Grands Ascensions Maritimes," the British Channel is the proper field for trying maritime ascents and determining which are the best means for rendering balloons serviceable on sea as well as on land. I have had several conversations with Lhoste, my aëronautical pupil, on the circumstances of his audacious trip. I will confine myself to the scientific teaching of this expedition.

The cone anchor was lowered by Lhoste when he saw that the Noëmi was running after the balloon, and diminished so much the velocity of the run that it was possible to catch him with a rowing boat. But although the wind was rather mild, the balloon inclined so much that the car was plunged into the water, and the waves drenched the occupant. It is evident that in st rmy weather the lowering of the cone anchor would lead $t \omega$ the destruction of the balloon by pressure of the wind. To avoid this it is necessary to reserve the cone anchor for ordinary wind ${ }^{\mathrm{c}}$, and to $\mathrm{u} \mathrm{e}$ in other circumstances guide-ropes with wooden nut: pased through them in order to increase friction as much as po sible.

The balloon went to the great altitude of 15,000 feet through the activity of the sun, which can be resisted very easily by taking some litres of water out of the sea, when nearing it, with a very simple apparatus that Lhoste has invented.

Any balloon attempting to cross the Channel should be bound to take on board half a dozen carrier pigeons to indicate the place where it has anchored, or has been rescued or landed, so that help could be sent to it without any delay. With such easy precautions, and the throwing out of a sufficient number of pilot balloons, the experiments can be conducted on scientific prin. ciples, and exert the most useful influence on the study of aërial currents on these seas, where several such currents combine, and where the constitution of the air is so peculiar that mirages of every descrip'ion have been frequently seen even at the present seas in.

Lhoste, on the morning of June 9, saw at an altitude of 1200 feet a re rular halo, which surrounded the sun. The fog was so heavy that he could not see the sea, except when it was almost ready to send him to a watery grave. The steam whistling from vessels in different seaports, reached him at every altitude; but he did not know what was the cause of the extraordinary noise.

If it had not been for the fog, Lhoste would bave succeeded in a scientific sport which will become fashionable, and ulti-

mately lead astronomy to try the air, and to trust to the winds in spite of Shakespeare.

Lhoste's audacity seems to have given rise to a competition in the Mediterranean from Marseilles, but I believe that the Mediterranean must only be tried when the British Channel has been traversed without difficulty in every direction, and that this part of the ocean will play an important part in the development of aërial navigation in the second century of its existence.

Boulogne, June 17

W. DE FonVielle

\title{
Geology of Cephalonia
}

CAN any of your readers kindly inform me whether geological investigations were ever made in the island of Cephalonia, one of the Ionian Islands that were under British protection up to the year 1863 ?

The following are the names of the fossils that $I$ have been able to determine out of those that were given to me and brought last year from Climatzias, Thermanti, and Leacas, localities in the neighbourhood of Mount Cephalos, in the island of Cephalonia :-

Mitra fusiformis, Brocc. M. Bronni, Mich. M. Michelotii, Hörnes. Buccinum costulatum, Brocc. B. prismaticum, Brocc. Chenopus pes pelecani, Phil. Triton Turbellianum, Grat. T. corrugatum, Law. Murex spinicosta, Bronn. Murex Murex

Fusus mitraformis, Brocc. F. virgineus, Grat. F. longirostris, Brocc. Turbinella subreticulata, d'Orb.

Bucuresti (Roumania), June 2

\author{
Cerithium Turritella turris, Bast. \\ Turritelle \\ Turritella - subangulata, Brocc. \\ Vermetus intortus, Lam. \\ Natica millepunctata, Lam. \\ Natica - \\ Dentalium \\ Venus multilamella, Lam. \\ V. plicata, Gmel. \\ Chama gryphoides, Linn. \\ Cardita 'fouanneti, Bast. \\ Fectunculus pilosus, Linn. \\ Limopsis calabra, Seguenza.
}

J. P. LICHERDOPOL

\section{Lightning Phenomenon}

WHILE watching the incessant play of vivid lightning during the progress of a thuaderstorm which was ragi ig close by in the country towards Novara, Arona being just on the northern limit, my wife observed the following curious spectacle, the account of which she wrote down immediately af erwards:-At 9.35 p.m. on Sunday, June 3, a meteor-like object was seen to pass apparently from suuth to north (window facin's due east), coming from the side of the storm and disappearing behind a mass of cloud which capped the high hill of Monte Val Grande above Layo Varese. It was oblately spheroid in form and apparently about the size of a fire-balluon, and with the velocity of a rocket was travelling slowly, for it left no visible track. It was of a bright, clear, whitish yellow, with a bright, pale green colour showing on the northern side when it passed behind the dark cloud. It wa about three times as high a hove the horizon as the low hills opposite Arona, and traversed an angle of $45^{\circ}$ horizontally from the point where first seen to its disappearance. The next day (June 4) when visiting friends at the Villa Frauzosine, near Tutra, we ascertaiı.ed that this meteor-like body had also been seen by two or three persons who were siting on a terrace watching the brillıant lightning to the south; they observed it moving also from south to north, disappearing behind the mountains to the northward. W. H. GoDwIN-A USTEN

\section{Waterspout}

ON April 28 last the Cunard steamship Serviu, in making her outward voyage to New York, fell in with several $s$ aall waterspouts. Being on deck at the time I made a rough sketch and some notes of the occurrence, which I now venture to send you, having learned that many officers of these steamers have sailed the North Atlantic for years without having witnessed any simi. lar phenomenon there. The ship's position may be easily deduced fro: $a$ the fact that her latitude was $42^{\circ} 24^{\prime}$ and longitude $51^{\circ} 3^{\prime}$ at noon on the 27 th, while the were $41^{\circ} 42^{\prime}$ and $59^{\circ} 53^{\prime}$ respectively at noon on the $28 \mathrm{th}$, at $8.30 \mathrm{a} . \mathrm{m}$. of which day we met the waterspouts. There was hardly any wind at the time, and 